\title{
THE BEHAVIORAL STUDY OF THE EFFECTS OF ATRISTAMINE ON THE SEROTONIN, DOPAMINE AND NOREPINEPHRINE NEUROTRANSMITTER SYSTEMS IN MICE
}

\author{
ILLYA PODOLSKY *, SERGIY SHTRYGOL' \\ National University of Pharmacy, Kharkiv, Ukraine \\ *corresponding author: illya.podolsky@nuph.edu.ua
}

Manuscript received: May 2018

\begin{abstract}
The present work reports the behavioural study of the effects on the serotonin, dopamine and norepinephrine neurotransmitter systems of 2-methyl-3-(phenylaminomethyl)-1H-quinolin-4-one (atristamine), a novel promising substance that exhibits excellent antidepressant effect combining with additional valuable neurotropic properties. The results indicate that the acute administration of atristamine increases the responsiveness of the adrenergic system. It has been proven by enhancement of clonidine-induced aggressive behaviour and attenuation of clonidine-induced depression in mice. It has been shown that atristamine attenuates haloperidol-induced catalepsy in mice, but this effect does not associate with MAO and COMT inhibition. A mild modulating effect of atristamine on the serotonin neurotransmitter system was discovered using 5-HTP induced head-twitch response in mice. It has been concluded that the antidepressant effect of atristamine may be explained predominantly by its complicated influence on the serotonin, dopamine and norepinephrine neurotransmitter systems.
\end{abstract}

\section{Rezumat}

Lucrarea de față prezintă studiul comportamental al efectelor asupra sistemelor de neurotransmițători serotonină, dopamină și norepinefrină ale 2-metil-3- (fenilaminometil) -1H-chinolin-4-onă (atristamina), o substanță promițătoare care prezintă un efect antidepresiv pronunțat, alături de alte proprietăți neurotropice. Rezultatele indică faptul că administrarea acută a atristaminei mărește capacitatea de reacție a sistemului adrenergic. Aceasta a fost dovedită prin creșterea comportamentului agresiv şi atenuarea depresiei induse de clonidină la şoareci. S-a demonstrat că atristamina atenuează catalepsia indusă de haloperidol, dar acest efect nu se asociază cu inhibarea MAO și COMT. Un efect modulator al atristaminei asupra sistemului serotoninergic a fost demonstrat utilizând un model experimental cu 5-HTP. S-a concluzionat că efectul antidepresiv al atristaminei poate fi explicat prin efectul său asupra serotoninei, dopaminei și norepinefrinei.

Keywords: 2-methyl-3-(phenylaminomethyl)-1H-quinolin-4-one, atristamine, clonidine-induced behaviour, haloperidolinduced catalepsy, head twitches response, L-DOPA induced hyperactivity

\section{Introduction}

Mental disorders comprise a broad range of issues manifested with different symptoms. Generally, they may be characterized as a complex combination of abnormal thoughts, emotions, behaviour and relationships with others [26]. Mental health problems are one of the main causes of the burden of disease worldwide [28]. According to the Global Burden of Disease Study (2010), depression and anxiety are the most predominant mental health problems worldwide [29].

Treatment of mental disorders often includes the use of drugs. Drugs can play a key role in treating many mental disorders and conditions. Antidepressants, anti-anxiety drugs, antipsychotics, stimulants and mood stabilizers are often used for these purposes [4]. The key commonality of their mechanisms of action is the regulative effects on the neurotransmitter systems in the CNS. All of them are effective and allow correcting even severe conditions. However, the long-term administration of these drugs may cause development of serious adverse effects. As a result, many patients have to discontinue taking drugs within the first year. Thus, notwithstanding the abundance of modern medicines, the goal to develop an "ideal drug" has not been reached yet and is still of great interest.

Unfortunately, absolutely new or innovative drugs for relieving mental disorders do not often appear. It is not a simple task to find insufficiently studied and, at the same time, promising classes of chemical compounds.

The new substance - 2-methyl-3-(phenylaminomethyl)-1H-quinolin-4-one (know under the name of atristamine) is now extensively studied in the National University of Pharmacy (Kharkiv, Ukraine) (Figure 1). 
<smiles>Cc1[nH]c2ccccc2c(=O)c1CNc1ccccc1</smiles>

Figure 1.

The structural formula of 2-methyl-3-(phenylaminomethyl)-1H-quinolin-4-one (atristamine)

Atristamine exhibits excellent antidepressant properties on the experimental models of depression [19, 22, 23]. It also possesses the anti-amnesic, cerebroprotective, antihypoxic, actopropective and analgesic activities [14-18].

Earlier studies using ELISA methods have been found that a reliable decrease in the concentration of serotonin $(-16.8 \%, \mathrm{p}<0.05)$ was consistent with the increased levels of dopamine $(+22.0 \%)$ and epinephrine $(+13.0 \%)$ in the brain of mice after administration of atristamine in the dose of 100 $\mathrm{mg} / \mathrm{kg}$ bw [24]. Thus, pharmacological effects of atristamine were associated with these changes. But the behavioural equivalents and contributions of each neurotransmitter system have not been evaluated yet.

Different effects of atristamine on the neurotransmitter systems of the brain have been already discussed in one form or another in previous studies. For example, it has been shown that atristamine in the dose of $100 \mathrm{mg} / \mathrm{kg}$ bw has an insignificant influence on the GABA-ergic system (on the models of thiosemicarbazide-induced seizures and thiopental-induced narcosis in mice), glycineergic structures (on the model of strychnineinduced seizures in mice) and mildly modulates the purinergic system (decreases the anxiogenic effect of caffeine in the open field test in mice) [20].

Furthermore, antagonism with reserpine has been proven for atristamine on the model of depression in rats [22]. It is well known that reserpine when given to various animal species produces a characteristic set of behaviours, including ptosis, hypothermia, huddling, inactivity, social withdrawal, and sedation. These and other behavioural changes have been likened to human depression. But, reserpine has so many different neurochemical effects that it is difficult to determine which mechanism is associated with which behaviours [10].

The present paper aimed to determine the interrelations between the effects of atristamine and serotonin, dopamine and norepinephrine neurotransmitter systems in vivo using the corresponding pharmacological analysers.

\section{Materials and Methods}

\section{Animals}

Adult random-bred male albino mice with the body weight of $18-24 \mathrm{~g}$ were included in the present study. The animals were obtained from the vivarium of the Central Research Laboratory (National University of Pharmacy, Kharkiv, Ukraine). Experiments were carried out in accordance with "Directive 2010/63/EU of the European Parliament and of the Council of 22 September 2010 on the protection of animals used for scientific purposes". The mice were kept in standard polypropylene cages at 20 $26^{\circ} \mathrm{C}$ and $50 \%$ humidity in a well-ventilated room in the $12 \mathrm{~h} \mathrm{light/dark}$ cycle with free access to food and water [3]. All experimental protocols were approved by the Bioethics Commission of the National University of Pharmacy.

Drugs and Chemicals

Atristamine (2-methyl-3-(phenylaminomethyl)-1Hquinolin-4-one) was synthesized at the Medicinal Chemistry Department of the National University of Pharmacy (Kharkiv) as reported [30]. In all experiments atristamine was administered intragastrically (i.g.) as an aqueous fine suspension stabilized with Tween 80 . The mice from the vehicle control groups received saline i.g. by the similar scheme. The volume of liquid that the animals in all groups received was similar and equalled to $0.1 \mathrm{~mL} / 10 \mathrm{~g}$ bw.

Clonidine hydrochloride, L-3,4-dihydroxyphenylalanine (L-DOPA), 5-hydroxytryptophane (5-HTP) were obtained from Sigma Chemical Company (USA). Haloperidol was used in the form of the solution for injection $5 \mathrm{mg} / \mathrm{mL}$ (trade name "Halopril", Zdorovye Narodu, Kharkiv, Ukraine).

Imipramine hydrochloride was chosen as the reference drug for the model of clonidine-induced aggressive behaviour to assess the effect of acute administration of classical tricyclic antidepressants on aggressive response of mice. Imipramine was used in the form of the solution for injection, $25 \mathrm{mg} / 2 \mathrm{~mL}$ (trade name "Melipramine", EGIS Pharmaceuticals PLC, Hungary).

Solutions were prepared ex tempore on the days of the experiment by dissolving drugs in physiological saline $(0.9 \% \mathrm{NaCl})$ or diluting with it. Pharmacological analysers and reference drug solutions were introduced intraperitoneally (i.p.).

Pharmacological tests

All behavioural experiments were performed between 9:00 and 16:00 $\mathrm{h}$ in a quiet room, at $23-26^{\circ} \mathrm{C}$.

\section{Clonidine-induced aggressive behaviour}

For this test, animals were divided into 4 groups:

Group 1 - vehicle control group of animals treated with saline (i.g.) before i.p. injection of saline $(10 \mathrm{~mL} / \mathrm{kg}$ bw), $\mathrm{n}=8$. This group was formed to check the aggressiveness of mice without chemical induction. 
FARMACIA, 2019, Vol. 67, 2

Group 2 - positive control group of animals introduced with saline (i.g.) before i.p. injection of clonidine solution, $\mathrm{n}=8$.

Group 3 - group of animals treated with atristamine $(100 \mathrm{mg} / \mathrm{kg}$ bw, i.g.) before i.p. injection of clonidine solution, $\mathrm{n}=8$.

Group 4 - group of animals treated with imipramine $(25 \mathrm{mg} / \mathrm{kg}$ bw, i.p.) before i.p. injection of clonidine solution, $\mathrm{n}=8$.

Clonidine was injected in the dose of $10 \mathrm{mg} / \mathrm{kg} \mathrm{bw}$ $1 \mathrm{~h}$ after introduction of atristamine, imipramine or saline. Immediately after that groups of 2 mice each were placed together in glass cylinders and were observed for $1 \mathrm{~h}$. Aggression was expressed as the number of biting attacks among 2 mice within $1 \mathrm{~h}$ [11].

\section{Clonidine-induced depressive behaviour}

Animals were randomly assigned into 3 groups:

Group 1 - vehicle control group treated with saline

$(10 \mathrm{~mL} / \mathrm{kg}$ bw, i.g.) before saline i.p. injection (10 $\mathrm{mL} / \mathrm{kg}$ bw), $\mathrm{n}=7$.

Group 2 - animals introduced with saline $(10 \mathrm{~mL} /$ $\mathrm{kg}$ bw, i.g.) before clonidine injection (i.p.), $\mathrm{n}=8$.

Group 3 - animals pretreated with atristamine (100 $\mathrm{mg} / \mathrm{kg}$ bw, i.g.) before clonidine injection (i.p.), $\mathrm{n}=8$. One hour after the single administration of atristamine or saline, clonidine was injected i.p. in the dose of $0.5 \mathrm{mg} / \mathrm{kg}$ bw. Animals of the vehicle control group were injected with the corresponding volume of saline. The open field test was used for the activity measurements $60 \mathrm{~min}$ after introduction of clonidine [7].

\section{Haloperidol-induced catalepsy}

For this experiment animals were randomly divided into 2 groups:

Group 1 - animals introduced with saline $(10 \mathrm{~mL} /$ $\mathrm{kg}$ bw, i.g.) before haloperidol injection (i.p.), $\mathrm{n}=8$.

Group 2 - animals treated with atristamine (100 $\mathrm{mg} / \mathrm{kg}$ bw, i.g.) before haloperidol injection (i.p.), $\mathrm{n}=8$. Catalepsy was induced with haloperidol $(1 \mathrm{mg} / \mathrm{kg}$ bw, i.p.) and measured at 30-min intervals by means of the standard bar test [6]. This dose of haloperidol was chosen to induce a moderate degree of catalepsy, so that either attenuation or potentiation of the phenomenon could be detected. Atristamine in the dose of $100 \mathrm{mg} / \mathrm{kg}$ bw and saline for the control group were introduced i.g. $60 \mathrm{~min}$ before haloperidol i.p. injection.

At each time-point, both forepaws of the animal were gently imposed on the 3-mm-diameter wooden bar fixed horizontally $4 \mathrm{~cm}$ above the support. The length of time during which each animal maintained the initial position was measured. Mice were considered to be cataleptic if they maintained this position for $30 \mathrm{~s}$ or more. The end point of catalepsy was considered to occur when both forepaws were removed from the bar or if the animal moved its head in an exploratory manner. A cut-off time of $180 \mathrm{~s}$ was applied. Between time-point determinations the animals returned to their cages.

\section{L-DOPA induced hyperactivity}

For this experiment, animals were randomly assigned into 5 groups:

Group 1 - vehicle control group treated with saline (i.g.) one hour before saline i.p. injection, $\mathrm{n}=8$.

Group 2 - animals treated with atristamine $(100 \mathrm{mg} / \mathrm{kg}$ bw, i.g.) one hour before saline i.p. injection, $\mathrm{n}=8$. Group 3 - negative control group treated with 100 $\mathrm{mg} / \mathrm{kg}$ bw of L-DOPA i.p. (too little dose for any manifestations of hyperactivity) one hour after saline i.g. introduction, $\mathrm{n}=7$.

Group 4 - animals treated with atristamine (100 $\mathrm{mg} / \mathrm{kg}$ bw, i.g.) one hour before L-DOPA injection in the dose of $100 \mathrm{mg} / \mathrm{kg}$ bw, $\mathrm{n}=8$.

Group 5 - positive control group treated with 500 $\mathrm{mg} / \mathrm{kg}$ bw of L-DOPA i.p. one hour after saline i.g. introduction, $\mathrm{n}=8$.

When mice were injected with L-DOPA stages of activity and aggressive behaviour were determined by a scoring system at every $15 \mathrm{~min}$ for $90 \mathrm{~min}$ after L-DOPA injection [25]. The different parameters of observation were piloerection, salivation, exophthalmos and hyperactivity. The scores were graded in the following manner: 0 - no effect; 1 - slight effect; 2 - moderate effect; 3 marked effect. The total score in each time-point was calculated as a general indicator of the animal's state.

\section{5-Hydroxytryptophan (5-HTP) induced head} twitches

For this experiment, animals were randomly assigned into 5 groups:

Group 1 - animals treated with atristamine (100 $\mathrm{mg} / \mathrm{kg}$ bw, i.g.) one hour before injection of saline $(10 \mathrm{~mL} / \mathrm{kg}$ bw, i.p.), $\mathrm{n}=8$.

Group 2 - negative control group treated with 50 $\mathrm{mg} / \mathrm{kg}$ bw of 5-HTP (i.p.) one hour after saline i.g. administration, $\mathrm{n}=8$.

Group 3 - animals treated with atristamine (100 $\mathrm{mg} / \mathrm{kg}$ bw, i.g.) one hour before 5-HTP injection in the dose of $50 \mathrm{mg} / \mathrm{kg}$ bw, $\mathrm{n}=8$.

Group 4 - positive control group treated with 300 $\mathrm{mg} / \mathrm{kg}$ bw of 5-HTP (i.p.) one hour after saline i.g. administration, $\mathrm{n}=7$.

Group 5 - animals pre-treated with atristamine (100 $\mathrm{mg} / \mathrm{kg}$ bw, i.g.) one hour before 5-HTP injection in the dose of $300 \mathrm{mg} / \mathrm{kg}$ bw, $\mathrm{n}=8$.

After 5-HTP or saline injection (group 1) each animal was placed in an individual cage, and the number of head twitches displayed by each mouse was counted. The number of head twitches for each animal within 1 minute was determined at the timepoints 10, 20, 30, 40, 50 and 60 minutes after 5-HT precursor introduction. The time intervals between measurements for each animal were maintained [1]. 
FARMACIA, 2019, Vol. 67, 2

Statistical analysis

The results are expressed as the mean (M) \pm standard error of the mean (SEM). Statistical differences between groups were analysed using Student's t-test (in the case of normal distribution), the Mann-Whitney U test, and the Fisher angular transformation. The level of statistical significance was considered as $\mathrm{p}<0.05$.

\section{Results and Discussion}

Clonidine-induced aggressive behaviour

Clonidine, an antihypertensive drug, has been reported to possess marked sedative effects in human and animals and is a useful therapeutic agent for the treatment of agitated mental patients in very low doses [12]. However, clonidine in higher doses produces aggressive behaviour such as biting and attacking in mice housed in pair or groups and automutilation in mice housed individually in the absence of objects to bite [21]. Clonidine stimulates $\alpha 2$-adenoceptors in lower doses and $\alpha$ l-receptors in higher doses. Therefore, the pro-aggressive effect of clonidine (in high doses of the drug, e.g. $10 \mathrm{mg} / \mathrm{kg} \mathrm{bw}$ ) results from the stimulation of the postsynaptic $\alpha 1$-adrenergic receptor. However, clonidine-induced aggressive behaviour also has been reported to involve blockade of central adenosine receptors [5, 27].

It has been concluded before that atristamine alone given acutely or repeatedly in the dose of 100 $\mathrm{mg} / \mathrm{kg}$ bw does not evoke any aggressive behaviour in mice.

As can be seen from Table I, a single dose (100 $\mathrm{mg} / \mathrm{kg}$ bw, i.g.) of atristamine enhances the effect induced by clonidine $(10 \mathrm{mg} / \mathrm{kg} \mathrm{bw})$, whereas a single dose of classical tricyclic antidepressant imipramine $(25 \mathrm{mg} / \mathrm{kg}$ bw, i.p.) significantly decreases the number of attacks. Animals of the vehicle control group had several situational attacks. However, it cannot be attributed to the signs of aggressive behaviour.

The effect of single injections of atristamine and imipramine on the clonidine-induced aggressive behaviour in

\begin{tabular}{|c|c|c|c|c|}
\hline \multirow{2}{*}{\begin{tabular}{c} 
Indicator \\
\cline { 2 - 5 }
\end{tabular}} & \multicolumn{4}{|c|}{ Group } \\
\cline { 2 - 5 } & Vehicle control group & Positive control group & $\begin{array}{c}\text { Atristamine, } \\
100 \mathrm{mg} / \mathrm{kg} \text { bw, i.g. }\end{array}$ & $\begin{array}{c}\text { Imipramine, } \\
25 \mathrm{mg} / \mathrm{kg} \text { bw, i.p. }\end{array}$ \\
\hline Number of attacks & $1.25 \pm 0.75$ & $30.3 \pm 1.4$ & $35.3 \pm 1.3^{*} / \wedge$ & $25.3 \pm 0.9^{*}$ \\
\hline First attack latency, $\mathrm{s}$ & $1020.0 \pm 665.6$ & $393.8 \pm 33.9$ & $305.0 \pm 20.3^{\wedge}$ & $455.0 \pm 24.1$ \\
\hline
\end{tabular}

Notes. * - significant compared to the positive control group; ${ }^{\wedge}$ - significant compared to the imipramine group (Mann-Whitney U test).

It should be noted that the latency to the first attack in the group receiving atristamine reduced by $22.5 \%$ compared to the positive control group, whereas imipramine, conversely, prolonged this indicator by $15.5 \%$.

It has been found that a number of typical and atypical antidepressants given chronically intensify clonidine-induced aggressiveness in mice. The data reported [9] supported further evidence for the hypothesis previously proposed that chronic, but not acute, administration of antidepressants enhances the responsiveness of central postsynaptic noradrenaline receptors. Antidepressants after acute administration exhibit contradictory effects depending on individual features.

Since the results of some experiments suggest that the clonidine-induced aggressive behaviour was not mediated through the alpha- 2 adrenoreceptor, but rather the adenosine receptor, so the influence of atristamine on the adenosine receptors cannot be excluded. It correlates well with modulating influence of atristamine on the anxiogenic effect of caffeine in the open field test in mice [20].

Clonidine-induced depressive behaviour

Low doses of clonidine produce hypoactivity in mice and rats probably by stimulating pre-synaptic alpha 2-adrenoceptors in the brain [7]. The hypoactivity following clonidine administration has been proposed as a test model for antidepressants with a noticeable effect on the noradrenergic system.

It has been found that chronic pre-treatment with most of antidepressants results in a significant reduction in the clonidine-induced hypoactivity. However, results of the studies of the effect with acute administration of different antidepressants are highly ambiguous [2, 7].

The present findings indicate that clonidine in the dose of $0.5 \mathrm{mg} / \mathrm{kg}$ bw produced a pronounced hypoactivity in mice (Table II) in the open field test. It has been proven by extremely decreased ambulation, explorative activity and significantly prolonged latency in this group of animals. Pretreatment with atristamine caused considerable, but not total, levelling of indicators in the open field test. The number of exploratory nose-pokes was the only indicator at the same level with the clonidine group.

Generally, clonidine $(0.5 \mathrm{mg} / \mathrm{kg}$ bw $)$ evoked a decrease in the total activity by 4.7 times $(\mathrm{p}<$ $0.001)$ compared to the vehicle group. Atristamine significantly reversed clonidine-induced depressive behaviour determined by an increase of the total 
FARMACIA, 2019, Vol. 67, 2

activity by 2.6 times $(\mathrm{p}<0.001)$ compared to the clonidine group.

Table II

The effects of atristamine on clonidine-induced depressive behaviour of mice in the open field test

\begin{tabular}{|c|c|c|c|}
\hline \multirow[b]{2}{*}{ Indicator } & \multicolumn{3}{|c|}{ Group, number of animals } \\
\hline & $\begin{array}{l}\text { Vehicle, } \\
\mathrm{n}=7\end{array}$ & $\begin{array}{c}\text { Clonidine, } 0.5 \mathrm{mg} / \mathrm{kg} \text { bw, } \\
\mathrm{n}=8\end{array}$ & $\begin{array}{c}\text { Clonidine, } 0.5 \mathrm{mg} / \mathrm{kg} \mathrm{bw}+ \\
\text { atristamine, } 100 \mathrm{mg} / \mathrm{kg} \mathrm{bw}, \\
\mathrm{n}=8\end{array}$ \\
\hline Latency, s & $1.9 \pm 0.3$ & $5.9 \pm 2.5^{*}$ & $1.5 \pm 0.3^{\wedge}$ \\
\hline \multicolumn{4}{|c|}{ I. Ambulation } \\
\hline Square crossings & $37.7 \pm 2.5$ & $11.4 \pm 1.8^{* * *}$ & $34.3 \pm 5.7^{\wedge \wedge \wedge}$ \\
\hline \multicolumn{4}{|c|}{ II. Explorative activity } \\
\hline Rearings & $7.7 \pm 1.8$ & $0.9 \pm 0.5^{* *}$ & $5.1 \pm 2.2^{\wedge}$ \\
\hline $\begin{array}{l}\text { Exploratory } \\
\text { nose-pokes }\end{array}$ & $34.0 \pm 3.2$ & $4.9 \pm 1.2^{* * *}$ & $5.8 \pm 0.9 * * *$ \\
\hline $\begin{array}{c}\text { Total explorative } \\
\text { activity }\end{array}$ & $41.7 \pm 2.1$ & $5.8 \pm 1.5^{* * *}$ & $10.9 \pm 2.1 * * * / \wedge$ \\
\hline \multicolumn{4}{|c|}{ III. Vegetative signs of emotional reactions } \\
\hline Faecal boli & $0.1 \pm 0.1$ & 0 & 0 \\
\hline Urinations & $0.1 \pm 0.1$ & $0.1 \pm 0.1$ & $0.4 \pm 0.3$ \\
\hline Groomings & $1.6 \pm 0.7$ & 0 & 0.1 \\
\hline $\begin{array}{c}\text { Total number of } \\
\text { emotional reactions }\end{array}$ & $1.9 \pm 0.9$ & $0.1 \pm 0.1$ & $0.5 \pm 0.3$ \\
\hline \multicolumn{4}{|c|}{ The total activity } \\
\hline $\mathrm{I}+\mathrm{II}+\mathrm{III}$ & $81.3 \pm 2.4$ & $17.3 \pm 3.0 * * *$ & $45.6 \pm 6.2^{* * / \wedge \wedge \wedge}$ \\
\hline
\end{tabular}

Notes. *, **,*** - significant with $\mathrm{p}<0.05, \mathrm{p}<0.01$ and $\mathrm{p}<0.001$ compared to the vehicle control group; ${ }^{\wedge}$ and ${ }^{\wedge \wedge \wedge}-$ significant $^{\text {with }} \mathrm{p}<$ 0.05 and $\mathrm{p}<0.001$ compared to the imipramine group (Mann-Whitney $\mathrm{U}$ test).

The above results indicate that acute administration of atristamine $(100 \mathrm{mg} / \mathrm{kg}$ bw) increases the responsiveness of the adrenergic system (behavioural changes).

Haloperidol-induced catalepsy

The phenomenon of cataleptic immobility induced in rodents by typical neuroleptics (e.g., haloperidol, chlorpromazine, fluphenazine) is a robust behavioural method for studying the nigrostriatal function and its modulation by cholinergic, serotonergic, nitrergic, and other neurotransmitter systems [13].

The present study was designed to determine the acute effect of atristamine on haloperidol-induced catalepsy in mice using the standard bar test.
As can be seen from Table III, haloperidol produced a moderate catalepsy with the maximal intensity being observed at 60-120 min time points. Pre-treatment with atristamine led to attenuation of haloperidol-induced catalepsy in mice. It was clearly observed at first and final time-points by significant reduction of catalepsy duration by $54.0 \%$ $(\mathrm{p}<0.05)$ and $64.7 \%(\mathrm{p}<0.05)$, respectively. At 60 150 min time-points atristamine also reduced the severity of catalepsy compared to control; it was determined by a short duration of catalepsy and decreased number of animals with total catalepsy. Thus, it may be concluded that atristamine causes certain activating effects on the dopaminergic neurotransmitter system attenuating the cataleptogenic effect of haloperidol.

Table III

The effects of atristamine on haloperidol-induced catalepsy in the bar test

\begin{tabular}{|c|c|c|c|c|c|c|c|}
\hline $\begin{array}{l}\text { Group of } \\
\text { animals }\end{array}$ & Parameter & $30 \mathrm{~min}$ & $60 \mathrm{~min}$ & $90 \mathrm{~min}$ & $120 \mathrm{~min}$ & $150 \mathrm{~min}$ & $180 \mathrm{~min}$ \\
\hline \multirow{2}{*}{$\begin{array}{c}\text { Saline }+ \\
\text { haloperidol, } \\
1 \mathrm{mg} / \mathrm{kg} \text { bw }\end{array}$} & $\begin{array}{l}\text { Duration of } \\
\text { catalepsy, s }\end{array}$ & $107.0 \pm 23.8$ & $127.4 \pm 21.2$ & $139.0 \pm 17.2$ & $113.9 \pm 20.6$ & $99.6 \pm 21.7$ & $58.4 \pm 17.9$ \\
\hline & $\begin{array}{l}\text { Animals with } \\
\text { total catalepsy }\end{array}$ & $3 / 8$ & $4 / 8$ & $4 / 8$ & $3 / 8$ & $2 / 8$ & $0 / 8$ \\
\hline \multirow{2}{*}{$\begin{array}{c}\text { Atristamine, } \\
100 \mathrm{mg} / \mathrm{kg} \mathrm{bw}+ \\
\text { haloperidol, } \\
1 \mathrm{mg} / \mathrm{kg} \mathrm{bw}\end{array}$} & $\begin{array}{l}\text { Duration of } \\
\text { catalepsy, s }\end{array}$ & $48.8 \pm 22.0^{*}$ & $97.8 \pm 22.7$ & $89.5 \pm 20.6$ & $67.9 \pm 21.5$ & $48.1 \pm 18.4$ & $20.6 \pm 10.6^{*}$ \\
\hline & $\begin{array}{l}\text { Animals with } \\
\text { total catalepsy }\end{array}$ & $1 / 8$ & $2 / 8$ & $2 / 8$ & $1 / 8$ & $0 / 8^{\wedge}$ & $0 / 8$ \\
\hline
\end{tabular}

Notes. * - significant with $\mathrm{p}<0.05$ compared to the vehicle control group (Mann-Whitney $\mathrm{U}$ test); ${ }^{\wedge}$ - significant with $\mathrm{p}<0.05$ compared to the saline control group (Fisher angular transformation).

As well known, despite the pharmacological heterogeneity of selective serotonin reuptake inhibitors (SSRIs), they consistently attenuate neuroleptic-induced catalepsy [13]. However, non- 
FARMACIA, 2019, Vol. 67, 2

selective antidepressants (including tricyclic ones) have contradictory results when tested on the models of catalepsy caused by neuroleptics.

\section{L-DOPA-induced hyperactivity}

According to the data published a low dose of LDOPA is insufficient to cause any visible signs of the hyperdopaminergic state, while a high dose
$(500 \mathrm{mg} / \mathrm{kg} \mathrm{bw})$ of the catecholamine precursor LDOPA in animals produces autonomic and behavioural changes (piloerection, sweating, salivation, acceleration of respiratory rate, hyperactivity and irritability), which have been attributed to the newly formed products of its catabolic degradation (especially, dopamine) [8].

Table IV

The effects of atristamine on L-DOPA-induced hyperactivity in mice

\begin{tabular}{|c|c|c|c|c|c|}
\hline Group & Piloerection & Hypersalivation & Exophthalmos & Hyperactivity & Score sum \\
\hline \multicolumn{6}{|c|}{15 min after L-DOPA injection } \\
\hline Vehicle & $0.0 \pm 0.0$ & $0.0 \pm 0.0$ & $0.0 \pm 0.0$ & $0.0 \pm 0.0$ & $0.0 \pm 0.0$ \\
\hline Atristamine & $0.0 \pm 0.0$ & $0.0 \pm 0.0$ & $0.0 \pm 0.0$ & $0.0 \pm 0.0$ & $0.0 \pm 0.0$ \\
\hline L-DOPA 100 & $3.00 \pm 0.0$ & $0.0 \pm 0.0$ & $2.57 \pm 0.20$ & $1.00 \pm 0.0$ & $6.57 \pm 0.20$ \\
\hline L-DOPA $100+$ atristamine & $3.00 \pm 0.0$ & $0.25 \pm 0.16^{\wedge \wedge \wedge}$ & $2.87 \pm 0.13$ & $1.50 \pm 0.33$ & $7.63 \pm 0.32 * / \wedge$ \\
\hline L-DOPA 500 & $3.00 \pm 0.0$ & $1.75 \pm 0.31$ & $3.00 \pm 0.0$ & $1.50 \pm 0.19$ & $9.25 \pm 0.49$ \\
\hline \multicolumn{6}{|c|}{30 min after L-DOPA injection } \\
\hline Vehicle & $0.0 \pm 0.0$ & $0.0 \pm 0.0$ & $0.0 \pm 0.0$ & $0.0 \pm 0.0$ & $0.0 \pm 0.0$ \\
\hline atristamine & $0.0 \pm 0.0$ & $0.0 \pm 0.0$ & $0.0 \pm 0.0$ & $0.0 \pm 0.0$ & $0.0 \pm 0.0$ \\
\hline L-DOPA 100 & $2.85 \pm 0.14$ & $0.0 \pm 0.0$ & $2.14 \pm 0.34$ & $1.00 \pm 0.0$ & $6.00 \pm 0.44$ \\
\hline L-DOPA $100+$ atristamine & $2.50 \pm 0.19$ & $2.00 \pm 0.38^{* * *}$ & $3.00 \pm 0.0^{*}$ & $1.75 \pm 0.31 *$ & $9.25 \pm 0.49 * * *$ \\
\hline L-DOPA 500 & $2.88 \pm 0.13$ & $2.38 \pm 0.26$ & $2.88 \pm 0.13$ & $1.88 \pm 0.13$ & $10.0 \pm 0.50$ \\
\hline \multicolumn{6}{|c|}{45 min after L-DOPA injection } \\
\hline Vehicle & $0.0 \pm 0.0$ & $0.0 \pm 0.0$ & $0.0 \pm 0.0$ & $0.0 \pm 0.0$ & $0.0 \pm 0.0$ \\
\hline Atristamine & $0.0 \pm 0.0$ & $0.0 \pm 0.0$ & $0.0 \pm 0.0$ & $0.0 \pm 0.0$ & $0.0 \pm 0.0$ \\
\hline L-DOPA 100 & $2.28 \pm 0.29$ & $0.0 \pm 0.0$ & $1.57 \pm 0.43$ & $0.57 \pm 0.20$ & $4.42 \pm 0.87$ \\
\hline L-DOPA $100+$ Atristamine & $1.25 \pm 0.31 * / \wedge \wedge \wedge$ & $2.50 \pm 0.27 * * *$ & $1.50 \pm 0.33^{\wedge \wedge}$ & $1.38 \pm 0.26^{* / \wedge \wedge}$ & $6.63 \pm 0.73^{\wedge \wedge \wedge}$ \\
\hline L-DOPA 500 & $3.00 \pm 0.0$ & $2.62 \pm 0.18$ & $2.75 \pm 0.16$ & $2.63 \pm 0.18$ & $11.0 \pm 0.42$ \\
\hline \multicolumn{6}{|c|}{60 min after L-DOPA injection } \\
\hline Vehicle & $0.0 \pm 0.0$ & $0.0 \pm 0.0$ & $0.0 \pm 0.0$ & $0.0 \pm 0.0$ & $0.0 \pm 0.0$ \\
\hline Atristamine & $0.0 \pm 0.0$ & $0.0 \pm 0.0$ & $0.0 \pm 0.0$ & $0.0 \pm 0.0$ & $0.0 \pm 0.0$ \\
\hline L-DOPA 100 & $0.86 \pm 0.34$ & $0.0 \pm 0.0$ & $0.43 \pm 0.20$ & $0.29 \pm 0.18$ & $1.57 \pm 0.65$ \\
\hline L-DOPA $100+$ atrista & $0.13 \pm 0.13^{\wedge \wedge \wedge}$ & $1.63 \pm 0.32 * * * / \wedge \wedge$ & $0.50 \pm 0.19^{\wedge \wedge \wedge}$ & $1.00 \pm 0.0 * * / \wedge \wedge \wedge$ & $3.25 \pm 0.50^{\wedge \wedge \wedge}$ \\
\hline L-DOPA 500 & $2.38 \pm 0.18$ & $2.75 \pm 0.16$ & $2.88 \pm 0.13$ & $3.00 \pm 0.0$ & $11.0 \pm 0.19$ \\
\hline \multicolumn{6}{|c|}{75 min after L-DOPA injection } \\
\hline Vehicle & $0.0 \pm 0.0$ & $0.0 \pm 0.0$ & $0.0 \pm 0.0$ & $0.0 \pm 0.0$ & $0.0 \pm 0.0$ \\
\hline Atristamine & $0.0 \pm 0.0$ & $0.0 \pm 0.0$ & $0.0 \pm 0.0$ & $0.0 \pm 0.0$ & $0.0 \pm 0.0$ \\
\hline L-DOPA 100 & $0.0 \pm 0.0$ & $0.0 \pm 0.0$ & $0.0 \pm 0.0$ & $0.0 \pm 0.0$ & $0.0 \pm 0.0$ \\
\hline L-DOPA $100+$ atrista & $0.0 \pm 0.0^{\wedge \wedge \wedge}$ & $0.0 \pm 0.0^{\wedge \wedge \wedge}$ & $0.0 \pm 0.0^{\wedge \wedge \wedge}$ & $0.0 \pm 0.0^{\wedge \wedge \wedge}$ & $0.0 \pm 0.0^{\wedge \wedge \wedge}$ \\
\hline L-DOPA 500 & $1.50 \pm 0.19$ & $2.75 \pm 0.16$ & $2.25 \pm 0.37$ & $2.00 \pm 0.33$ & $8.50 \pm 0.80$ \\
\hline \multicolumn{6}{|c|}{90 min after L-DOPA injection } \\
\hline Vehicle & $0.0 \pm 0.0$ & $0.0 \pm 0.0$ & $0.0 \pm 0.0$ & $0.0 \pm 0.0$ & $0.0 \pm 0.0$ \\
\hline Atristamine & $0.0 \pm 0.0$ & $0.0 \pm 0.0$ & $0.0 \pm 0.0$ & $0.0 \pm 0.0$ & $0.0 \pm 0.0$ \\
\hline L-DOPA 100 & $0.0 \pm 0.0$ & $0.0 \pm 0.0$ & $0.0 \pm 0.0$ & $0.0 \pm 0.0$ & $0.0 \pm 0.0$ \\
\hline L-DOPA $100+$ atristamine & $0.0 \pm 0.0$ & $0.0 \pm 0.0^{\wedge \wedge \wedge}$ & $0.0 \pm 0.0$ & $0.0 \pm 0.0$ & $0.0 \pm 0.0^{\wedge \wedge \wedge}$ \\
\hline L-DOPA 500 & $0.38 \pm 0.18$ & $1.63 \pm 0.32$ & $0.50 \pm 0.27$ & $0.50 \pm 0.27$ & $3.00 \pm 0.66$ \\
\hline
\end{tabular}

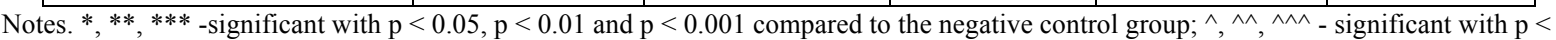
$0.05, \mathrm{p}<0.01$ and $\mathrm{p}<0.001$ compared to the positive control group (Student's t-test).

As can be seen from Table IV and Figure 2, animals from the positive control group treated with $500 \mathrm{mg} / \mathrm{kg}$ bw L-DOPA had strongly pronounced signs of L-DOPA excitation (piloerection, hypersalivation, exophthalmos and hypercativity) for almost all observation times. Animals from the negative control group treated with the low dose of L-DOPA (100 mg/kg bw) had a pronounced piloerection and exophthalmos, but not hypersalivation and hyperactivity in the early timepoints. After $45 \mathrm{~min}$ exposure the signs of L-DOPA administration started to decrease dramatically and in $60 \mathrm{~min}$ only insignificant symptoms were observed. Animals pre-treated with atristamine in early stages of the L-DOPA hyperactivity development had scores similar to the positive control group (500 mg/kg bw of L-DOPA) but in $30 \mathrm{~min}$ of exposure all visual signs started to decrease dramatically approaching to the results of the negative control group $(100 \mathrm{mg} / \mathrm{kg}$ bw of LDOPA). 


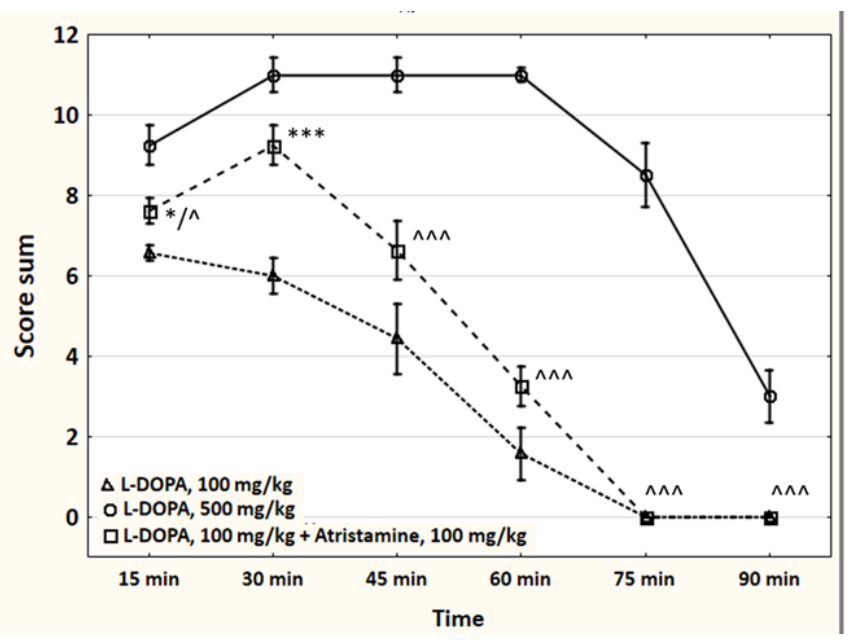

Figure 2.

The effects of atristamine on the L-DOPA-induced hyperactivity in mice

$\left(*, * * *\right.$ - significant with $\mathrm{p}<0.05$ and $\mathrm{p}<0.001$ compared to the negative control group; ${ }^{\wedge}$ and ${ }^{\wedge \wedge \wedge}-$ significant with $\mathrm{p}<0.05$ and $\mathrm{p}<0.001$ compared to the positive control group (Student's t-test))

The present findings indicate that atristamine probably does not have MAO and COMT inhibition as the main mechanism of its antidepressant action. Otherwise, potentiation and prolongation of the LDOPA induced hyperactivity after pre-treatment with atristamine in mice would be observed. Potentiation of L-DOPA (100 mg/kg bw) by atristamine in early stages of the hyperactivity development may be explained by the activating effect on the dopaminergic system; it has been also found in the bar test described above.

5-Hydroxytryptophan (5-HTP) induced head twitches in mice

Corne et al. described a simple method for quantitative and qualitative assessment of effects of drugs on behavioural responses produced by administration of 5-HTP. They showed that in parallel with the increase of the brain concentration of serotonin a particular head-twitch phenomenon occurred in mice, and the presence or frequency of this head-twitch could be taken as a sensitive measure of the agonistic or antagonistic effect of drugs [1]. The head-twitch response consists of a rapid and violent head shaking and does not occur in normal mice.

It was previously found that imipramine, desipramine, and amitriptylline inhibited the headtwitch response, whereas MAOI consistently potentiated it [1].

Analysis of the experimental data presented in Table $\mathrm{V}$ has proven that atristamine per se does not evoke the head-twitch response in mice. Animals treated with a low dose of 5-HTP $(50 \mathrm{mg} / \mathrm{kg} \mathrm{bw})$ had an insignificant head-twitch response in mice that became almost indiscernible already $30 \mathrm{~min}$ after 5-HTP injection, whereas a high dose (300 $\mathrm{mg} / \mathrm{kg} \mathrm{bw})$ of the pharmacological analyser produced a strongly pronounced head-twitch phenomenon in animals.

Table V

The effects of atristamine on head-twitch responses of mice

\begin{tabular}{|c|c|c|c|c|c|c|}
\hline \multirow{2}{*}{ Group } & \multirow{2}{*}{$\mathrm{n}$} & \multicolumn{5}{|c|}{ Time-point } \\
\cline { 3 - 7 } & & $10 \mathrm{~min}$ & $20 \mathrm{~min}$ & $30 \mathrm{~min}$ & $40 \mathrm{~min}$ & $50 \mathrm{~min}$ \\
\hline Atristamine, $100 \mathrm{mg} / \mathrm{kg} \mathrm{bw}$ & 8 & 0 & 0 & 0 & 0 & 0 \\
\hline $5-\mathrm{HTP}, 50 \mathrm{mg} / \mathrm{kg} \mathrm{bw}$ & 8 & $1.38 \pm 0.42$ & $1.50 \pm 0.57$ & $0.25 \pm 0.16$ & 0 & 0 \\
\hline $\begin{array}{c}5-\mathrm{HTP}, 50 \mathrm{mg} / \mathrm{kg} \mathrm{bw}+ \\
\text { atristamine, } 100 \mathrm{mg} / \mathrm{kg} \mathrm{bw}\end{array}$ & 8 & $0.75 \pm 0.49$ & $0.75 \pm 0.25$ & $0.25 \pm 0.16$ & 0 & 0 \\
\hline $5-\mathrm{HTP}, 300 \mathrm{mg} / \mathrm{kg} \mathrm{bw}$ & 7 & $6.43 \pm 1.66$ & $8.43 \pm 2.06$ & $7.14 \pm 2.27$ & $5.14 \pm 1.37$ & $1.29 \pm 0.47$ \\
\hline $\begin{array}{c}5-\mathrm{HTP}, 300 \mathrm{mg} / \mathrm{kg} \mathrm{bw}+ \\
\text { atristamine, } 100 \mathrm{mg} / \mathrm{kg} \mathrm{bw}\end{array}$ & 8 & $5.50 \pm 1.05$ & $13.38 \pm 3.07$ & $10.75 \pm 2.79$ & $3.88 \pm 0.85$ & $1.75 \pm 0.49$ \\
\hline
\end{tabular}

Atristamine in the dose of $100 \mathrm{mg} / \mathrm{kg}$ bw introduced $1 \mathrm{~h}$ before the 5-HTP introduction in both doses (50 and $300 \mathrm{mg} / \mathrm{kg}$ bw) had no significant effect on the head-twitch response in mice. However, the results of animals pre-treated with atristamine before the injection of 5-HTP low dose tended to be lower compared to the saline pretreated group. And, vice versa, the results of animals received with atristamine and a high dose of 5-HTP prone to be higher than in the corresponding control group. Thus, in spite of the apparent absence of significant differences in 
FARMACIA, 2019, Vol. 67, 2

results they revealed complicated effects of atristamine on the 5-hydroxytryptamine neurotransmitter system even after a single dose. This influence can be described as modulating. It was concluded that atristamine most likely had no effect on MAO since potentiation and prolongation of the 5-HTP induced head-twitch response in both doses after pre-treatment with the compound tested were not observed.

\section{Conclusions}

Interrelations between the effects of atristamine and serotonin, dopamine and norepinephrine neurotransmitter systems in vivo using the corresponding pharmacological analysers have been studied. The above results indicate that acute administration of atristamine $(100 \mathrm{mg} / \mathrm{kg} \mathrm{bw})$ increases the responsiveness of the adrenergic system. It has been proven by the enhancement of clonidine-induced aggressive behaviour and the attenuation of clonidine-induced depression in mice. However, the influence of atristamine on the adenosine receptors cannot be excluded.

It has been shown that atristamine attenuates haloperidol-induced catalepsy in mice, but this effect does not associate with MAO and COMT inhibition. A mild modulating effect of atristamine on the serotonin neurotransmitter system was discovered using 5-HTP induced head-twitch response in mice. Consequences that could be produced by MAO inhibition also were not determined.

It has been concluded that the antidepressant action of atristamine may be explained predominantly by its complicated influence on the serotonin, dopamine and norepinephrine neurotransmitter systems. Certain correlations between results of atristamine and different antidepressants have been discussed.

\section{References}

1. Corne SG, Pickering RW, Warnet BT, A method for assessing the effects of drugs on the central actions of 5-hydroxytryptamine. British Journal of Pharmacology and Chemotherapy, 1963; 20: 106-120.

2. De Angelis L, Multiple administration of carbamazepine, typical and atypical antidepressant drugs on clonidine-induced hypoactivity in mice. In vivo, 1991; 5(4): 393-396.

3. Deacon RM, Housing, husbandry and handling of rodents for behavioral experiments. Nature Protocols, 2006; 1(2): 936-946.

4. FDA Homepage, http://www.fda.gov.

5. Fujiwara Y, Takeda T, Kazahaya Y, Otsuki S, Sandyk R, Inhibitory effects of carbamazepine on clonidine-induced aggressive behavior in mice. The Int J Neurosci., 1988; 42: 77-84.
6. Hattori K, Uchino S, Isosaka T, Maekawa M, Iyo $\mathrm{M}$, Fyn is required for haloperidol-induced catalepsy in mice. J Biol Chem., 2006; 281(11): 7129-7135.

7. Heal DJ, Lister S, Smith SL, Davies CL, Molyneux SG, Green AR, The effects of acute and repeated administration of various antidepressant drugs on clonidine-induced hypoactivity in mice and rats. Neuropharmacology, 1983; 22(8): 983-992.

8. Litvinov RA, Eliseeva NV, Grechko OY, Spasov AA, Influence of the kappa-opioid agonist RU1205 compound in wide spread of doses on the effects of neuromediator analyzers: Bechavioral testing. Clinical Research and Trials, 2017; 3(6): 1-7.

9. Maj J, Mogilnicka E, Klimek V, Kordecka-Magiera A, Chronic treatment with antidepressants: protentiation of clonidine-induced aggression in mice via noradrenergic mechanism. J Neural Transm., 1981; 52(3): 189-197.

10. McKinney WT. Models of mental disorders. a new comparative psychiatry. Plenum Medical Book: New York, 1988: 199.

11. Morpurgo C, Aggressive behaviour induced by large doses of 2-(2,6-dichlorophenyl amino)-2imidazoline hydrochloride (ST 155) in mice. Eur $J$ Pharmacol., 1968; 3(4): 374-377.

12. Nishikawa T, Tanaka M, Tsuda A, Kohno Y, Nagasaki N, Differential effects of clonidine on alpha 1- and alpha 2-adrenoceptors in footshockinduced jumping behavior. Eur $J$ Pharmacol., 1983; 88(4): 399-401.

13. Pires JGP, Bonikovski V, Futuro-Neto HA, Acute effects of selective serotonin reuptake inhibitors on neuroleptic-induced catalepsy in mice. Braz J Med Biol Res., 2005; 38(12): 1867-1872.

14. Podolsky I, Shtrygol' S, The analgesic properties of a promising antidepressant - 2-methyl-3-(phenylaminomethyl)-1H-quinolin-4-one. The Pharma Innovation Journal, 2017; 6(8): 156-160.

15. Podolsky IM, Shtrygol' SYu, Gritsenko IS, [The influence of promising antidepressant with nootropic properties 2-methyl-3-phenylaminomethylquinolin4-one on the phases of memory]. Ukrainskiy zhurnal klinichnoi ta laboratornoi medicini, 2013; 8(4): 104-107 (available in Ukrainian).

16. Podolsky IM, Shtrygol' SYu, Laryanovska YuB, [Experimental research of cerebroprotective effect of 2-methyl-3-phenylaminomethylquinolin-4-one against morphological damages in rat brain structures after traumatic brain injury]. Farmacom., 2015; 2: 68-76 (available in Ukrainian).

17. Podolsky IM, Shtrygol SYu, Neuroprotective activity of 2-methyl-3-phenylamino-methylquinolin-4-one in experimental traumatic brain injury in rats. Journal of Chemical and Pharmaceutical Research, 2015; 7(4): 518-524.

18. Podolsky IM, Shtrygol' SYu, Ostashko VF, Bezditko NV, [The research of antihypoxic activity of 2-methyl-3-phenylaminomethylquinolin-4-one perspective antidepressant with nootropic properties]. Ukrayins'kyy biofarmatsevtychnyy zhurnal, 2013; 2(25): 46-49 (available in Ukrainian).

19. Podolsky IM, Shtrygol' SYu, Zubkov VO, The psycho- and neurotropic profiling of novel 3-(N- 
$\mathrm{R}, \mathrm{R}^{\prime}$-aminomethyl)-2-methyl-1H-quinolin-4-ones in vivo. Saudi Pharmaceutical Journal, 2018; 26(1): 107-114.

20. Podolsky IN, Shtrygol' SYu, Zubkov VA, Gritsenko IS, [Interaction of perspective anti-depressant with nootropic properties 2-methyl-3-phenylaminomethylquinolin-4-one with CNS stimulants and depressants]. Meditsinskiy vestnik Yuga Rossii, 2014; 1: 80-84 (available in Russian).

21. Razzak A, Fujiwara M, Ueki S, Automutilation induced by clonidine in mice. Eur $J$ Pharmacol., 1975; 30(2): 356-359.

22. Shtrygol' SYu, Zubkov VA, Podolsky IN, Gritsenko IS, [2-Methyl-3-phenylaminomethylquinolin-4-on as potential antidepressant with nootropic properties]. Eksperimental'naya i Klinicheskaya Farmakologiya, 2012; 75(4): 7-9 (available in Russian).

23. Shtrygol' SYu, Zubkov VO, Hrytsenko IS, Podolsky IM, Shatilov OV, [Screening research of 3aminomethyl-2-methylquinolin-4-ones as potential psychotropic agents]. Klinichna farmatsiya, 2010; 14(1): 35-38 (available in Ukrainian).

24. Shtrygol' SYu, Zubkov VO, Podolsky IM, Hrytsenko IS, [The influence of 3-aminomethyl-2methylquinolin-4-one derivatives on monoamines levels in the brain of mice]. Visnyk farmatsiyi, 2011; 1(65): 62-65 (available in Ukrainian).

25. Suresh D, Madhu M, Saritha Ch, Raj kumar V, Shankaraiah P, Antidepressant activity of Spirulina platensis in experimentally induced depression in mice. International Journal of Research and Development in Pharmacy and Life Sciences, 2014; 3(3): 1026-1035.

26. The world health report 2001 - Mental Health: New Understanding, New Hope, World Health Organization, Geneva: $10 \mathrm{p}$.

27. Ushijima I, Katsuragi T, Furukawa T, Involvement of adenosine receptor activities in aggressive responses produced by clonidine in mice. Psychopharmacology, 1984; 83(4): 335-339.

28. GBD 2016 Disease and Injury Incidence and Prevalence Collaborators, Global, regional, and national incidence, prevalence, and years lived with disability for 328 diseases and injuries for 195 countries, 1990-2016: a systematic analysis for the Global Burden of Disease Study 2016. The Lancet, 2017; 390(10100): 1211-1259.

29. Whiteford HA, Degenhardt L, Rehm J, Baxter AJ, Ferrari AJ, Erskine HE, Charlson FJ, Global burden of disease attributable to mental and substance use disorders: findings from the Global Burden of Disease Study 2010. The Lancet, 2013; 382(9904): 1575-1586.

30. Zubkov VA, Gritsenko IS, Taran SG, Podolsky IN, Kamenetska OL, [3-Dimethylaminomethyl-2-methyl$1 \mathrm{~h}$-quinolin-4-one as an effective reagent in the 3aminomethylsubstituted quinolones synthesis]. Zhurnal orhanichnoyi ta farmatsevtychnoyi khimiyi, 2005; 3(2): 23-27 (available in Russian). 